\title{
The role of geotourism in supporting regeneration in disadvantaged rural communities in Ireland
}

\author{
P. J. O’Connor \\ Geological Survey of Ireland, Ireland
}

\begin{abstract}
The rural communities of the border area of north central Ireland have suffered economic and social deprivation as a consequence of civil conflict over a period of three decades. This prolonged strife has served to reduce the use of the countryside as an amenity and has hindered wider appreciation of the outstanding natural landscapes of the region. Recognising this, the two Geological Survey organisations on the island of Ireland (the Geological Survey of Ireland and the Geological Survey of Northern Ireland) have worked together since 1994 on a series of initiatives to try to address this problem and to assist the ongoing process of reconciliation among divided communities. Beginning with a project branded Landscapes from Stone, a series of popular and attractively illustrated maps and walking and touring guides were produced for the tourist market with funding support under the EU Programme for Peace and Reconciliation (Peace 1). There is still a strong ongoing demand for these products which cover the twelve northern counties of Ireland on both sides of the border and which received the endorsement of most local authorities. The latest and most ambitious initiative is now underway in the Breifne Project based on the natural and cultural resources of a distinct geographic and geological crossborder region, which embraces parts of Counties Cavan, Fermanagh, Leitrim, Roscommon and Sligo. The project is supported by the five local authorities, the Geological Survey of Ireland, the Geological Survey of Northern Ireland and the University of Ulster with funding being provided by the EU Special Programmes Body under the Peace 2 Programme.
\end{abstract}

Keywords: geotourism, sustainable rural tourism, ecotourism, European geoparks, peace and reconciliation, cross-border cooperation, EU support. 


\section{Introduction}

The economic and social impact of what has been euphemistically termed "the troubles" on communities in Northern Ireland and the border areas of the Republic of Ireland have been profound. These communities have endured civil conflict over an extended period of more than three decades from the late 1960's to the late 1990's. In border areas with the Republic of Ireland cross-border roads were cratered and closed in the early 1970's by the British security forces. This had the effect of creating separate communities in these rural areas leading to a loss of social integration and business interaction. Over time, mistrust built up between the divided communities which often led to civil strife at flashpoints along the border. A further effect was that employment opportunities were diminished significantly and people began to migrate from the area.

The Good Friday Agreement brokered by the British and Irish Governments in 1998 marked an end to sectarian conflict in Northern Ireland and the beginning of reconciliation and reconstruction. Today, huge moral and financial commitment is being provided by both Governments, with significant support from the European Commission and the U.S. Government, to accelerate the pace of regeneration and to overcome the legacy of mistrust.

\section{Birth of Geotourism in Ireland}

Landscapes, scenery and rocks can provide a non-contentious focus for communities of different cultural and social backgrounds to work towards a common goal and by so doing to achieve a common purpose (e.g. economic regeneration). Recognising this in the early 1990's, the two Geological Survey organisations on the island of Ireland (the Geological Survey of Ireland and the Geological Survey of Northern Ireland) set about developing a "geotourism" product based on the natural landscapes of the border area.

\subsection{The first cross-border pilot project}

The initial concept for a public-outreach geotourism project, jointly managed by the two Surveys, was first given substance in 1994 when the International Fund for Ireland provided funding for a pilot project in the Cavan-Fermanagh border area (fig. 1). The project was aimed at evaluating the potential for mineral development (particularly rock aggregates for housing and road construction) and the "geotourism" opportunities of the area, as outlined by O'Connor and Mitchell [1]. The success of the pilot project in 1996 encouraged both Surveys to embark on a more ambitious and strategic phase of cooperation aimed at spreading the economic and social benefits of landscape tourism throughout the northern part of Ireland. 


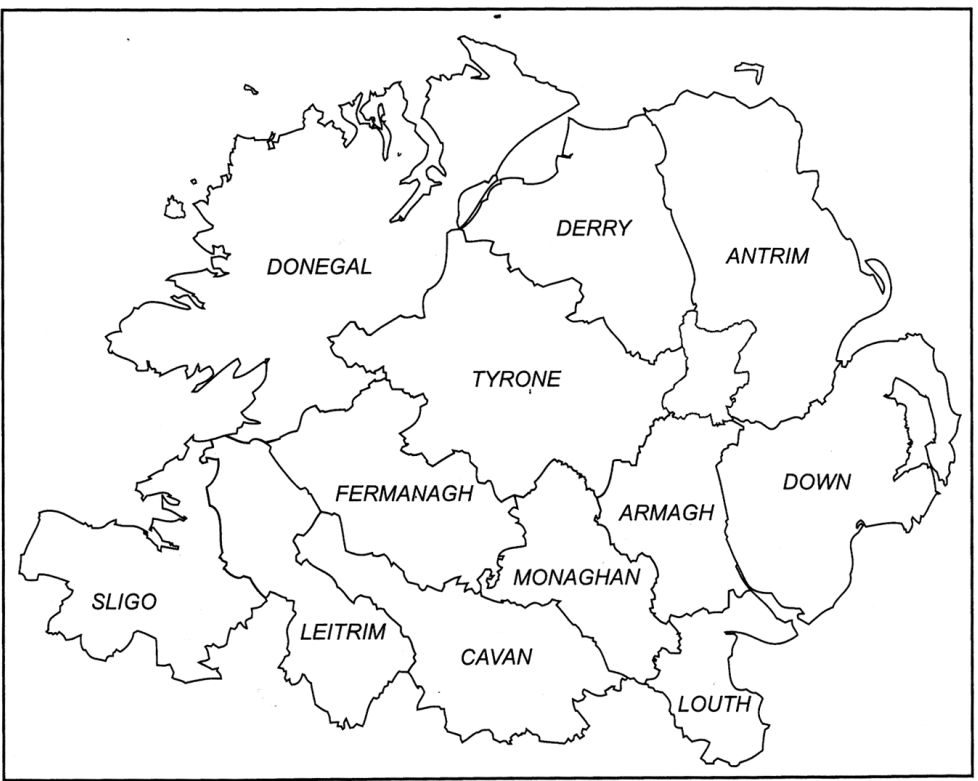

Figure 1: 12 Counties project area.

\subsection{Landscapes from Stone project}

In 1997 both Surveys embarked on a completely new joint initiative based on the landscape resources of northern Ireland - the region which embraces counties Antrim, Armagh, Cavan, Derry, Donegal, Down, Fermanagh, Leitrim, Louth, Monaghan, Sligo and Tyrone (fig. 1).

\subsubsection{The concept}

From discussions with Fáilte Ireland and the Northern Ireland Tourist Board at the outset of the project, it was realised that a specific branding and marketing initiative would be required to raise public awareness of the value of landscape tourism as a basis for economic regeneration across the region and to attract visitors to the region. At an early brain-storming session the project team developed the brand concept Landscapes from Stone followed by a brand logo (fig. 2). During the project formulation stage all of the local councils across the region were consulted for advice and support.

\subsubsection{Securing funding}

Following successful competitive applications, the EU Special Support Programme for Peace and Reconciliation (Peace 1) provided significant funding which underpinned the project in the period 1997 to 2002. Separate funds for the marketing initiative came from the EU INTERREG II Programme and further matching funds were provided by 27 of the 32 local authorities across the region. 


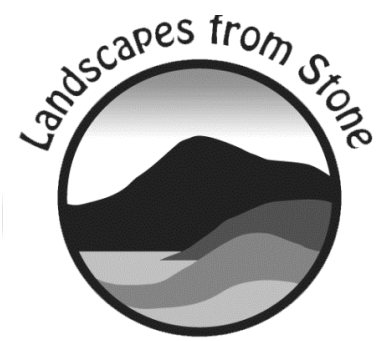

Figure 2: $\quad$ Landscapes logo.

\subsubsection{Product development}

Throughout the process of product development the project team maintained close contact with councils and community groups. These contacts proved vital in maintaining a focused approach and in developing products which were relevant to people's needs. In essence, four product types were developed over the five year period:

- Landscapes from Stone Map - Fourteen discreet landscape areas were defined on a satellite image base map of the region, each of which developed as a consequence of a specific geological event or series of events. Established walking trails and sites of cultural and archaeological importance were also included on the map by McKeever et al [2].

- A Story through Time - a book accompaniment to the landscapes map is a well illustrated popular guide to the geological evolution of the region by McKeever and Smyth [3].

- Explore Series - a series of eleven touring guides for car or bicycle covering the diverse landscapes of the region.

- Walk Series - a series of seven walks packs, each pack containing 10 loop walks featuring the geology and landscapes of particular subregions in more detail.

\subsubsection{Branding and marketing}

Copies of all publications were distributed widely to retail outlets and tourism offices throughout the region and the uptake of these products has been very encouraging. Many of the products are now being reprinted such has been the demand, details are available on the GSI website [4]. The Landscapes from Stone brand logo has proved very useful in linking the products together under one umbrella and in gaining brand recognition for the products among the general public.

\section{The Breifne project}

The Breifne Project commenced in 2003 and is focused on the upland region of Counties Cavan, Fermanagh, Leitrim, Roscommon and Sligo (fig. 3). The region is geographically and geologically distinct and this is reflected in many aspects 
of its culture and folklore. The region embraces visually stunning seascapes to the west, the high amenity Shannon and Erne waterways to the south and northeast and the classic drumlin landscapes to the east. The region also contains a UNESCO-designated European Geopark in the Cuilcagh Mountains at Marble Arch Caves, Co. Fermanagh. The Geopark was designated in 2001.

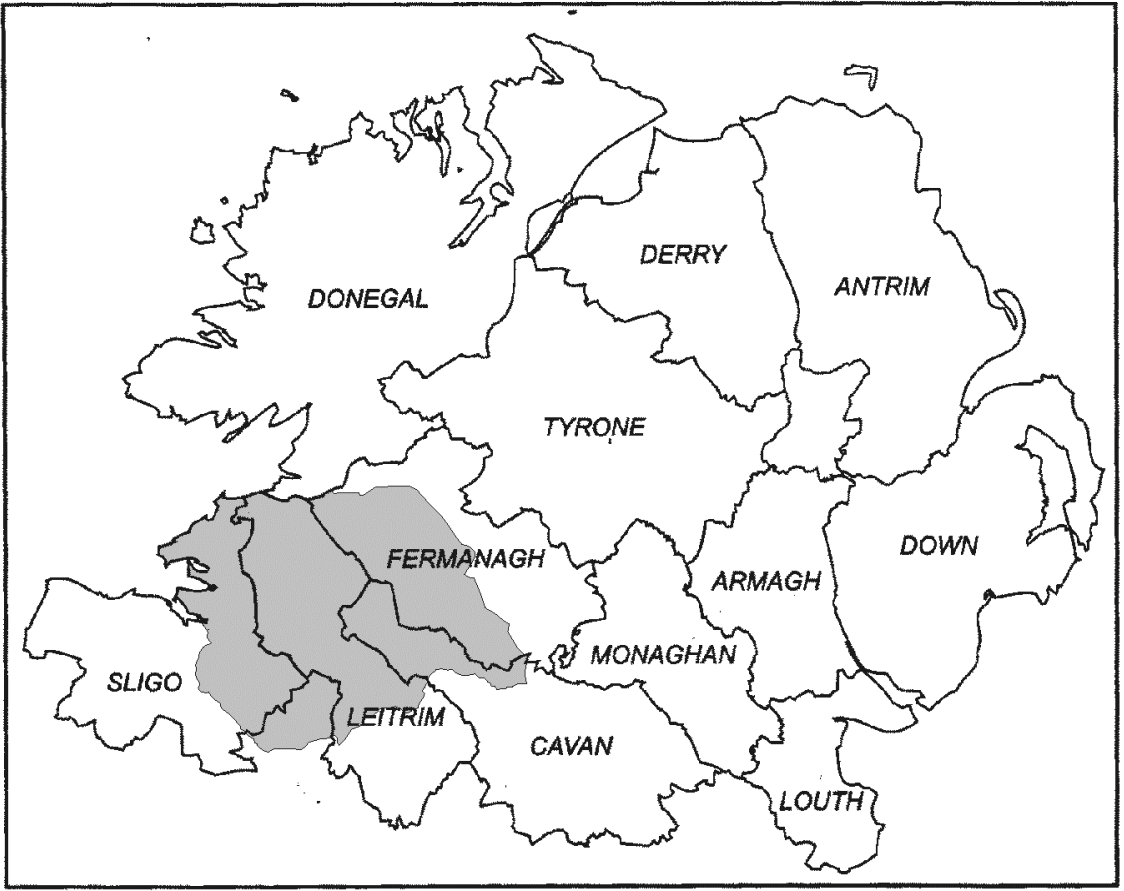

Figure 3: $\quad$ Outline of Breifne Project area.

\subsection{The concept}

The project was aimed at developing a sustainable cultural, heritage and geotourism product in north-western Ireland for an area where tourism has not yet flourished. Breifne is a brand-building cross-border initiative aimed at embracing all aspects of landscape - physical, cultural and heritage in a holistic manner.

\subsection{Securing funding}

Following a competitive application process, significant funding in excess of $€ 1.6$ million was received from the Special EU Programmes Body (SEUPB) under the Peace 2 Programme with matched funding of $€ 800,000$ being provided by the project partners. The partners include Cavan, Leitrim, Sligo and Roscommon County Councils, Fermanagh District Council, the Geological 
Survey of Ireland, the Geological Survey of Northern Ireland and the University of Ulster (Academy of Irish Cultural Heritages). A second tranche of funding was secured from SEUPB in 2007. The partners formed the Breifne Mountains Co. Ltd. with each organisation appointing Directors to the Board. Other Directors represent Fáilte Ireland and County tourism officers.

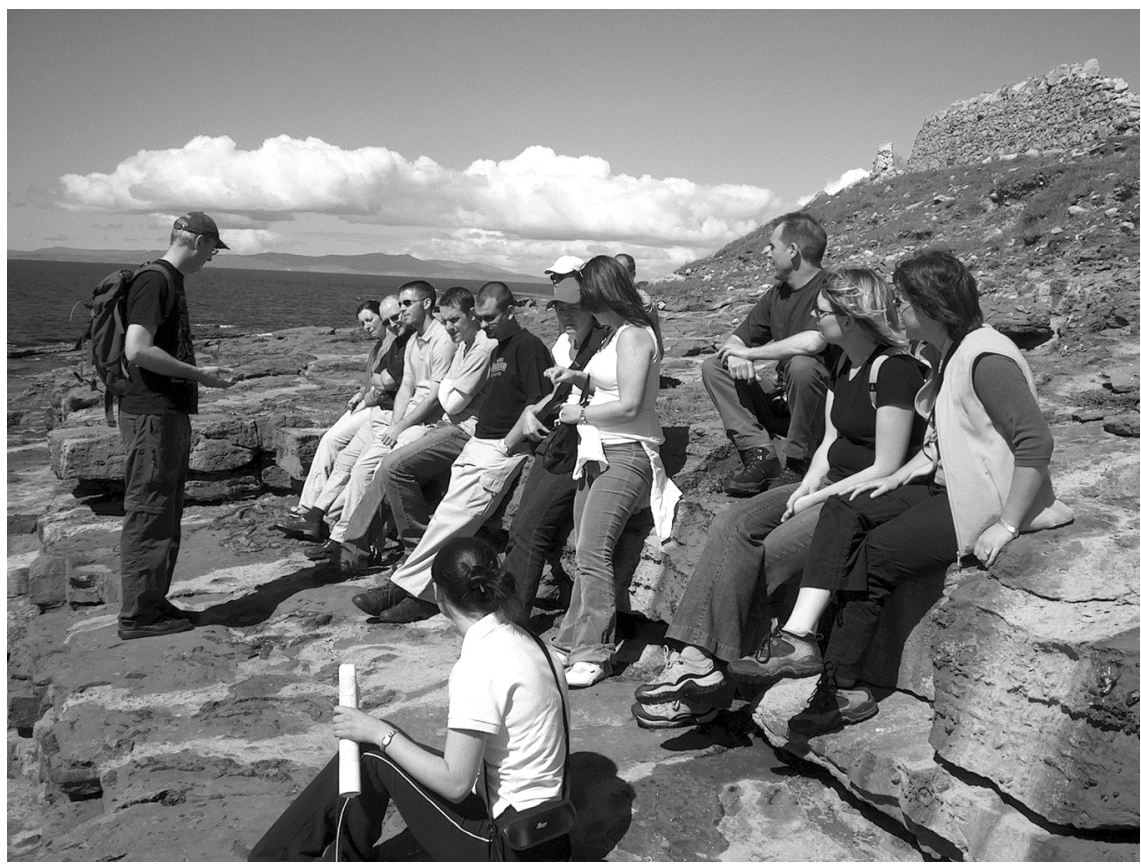

Figure 4: The project team on a field visit to the region.

\subsection{Building the project team}

A team of specialists was recruited in 2003 and 2004 comprising geologists, an ecologist, an archaeologist, an ethnologist/folklorist, two GIS/database specialists and a web-mapping specialist. The team was based at the Geological Survey offices in Dublin and at the University of Ulster in Derry. The multidisciplinary team was coordinated by a Project Director. At the commencement of the project, the team undertook an extended field visit to the region (fig. 4). This proved very effective in bonding the team together and in familiarising members with the detail of each others specialist areas.

\subsection{Product development}

The ultimate aim of the project was to underpin economic regeneration of a cross-border region and its communities through the development of a new, branded tourism destination Breifne. The project team built up a comprehensive natural and cultural resource inventory and database for the region over a three 
year period. This geo-referenced database provided the basis for the development of specific products aimed at attracting visitors to the region:

- Breifne Guidebook - a 200-page full colour guidebook aimed at the discerning visitor was published in 2006 and over 10,000 copies have been distributed to date. The guidebook covers the geology and landscapes, the ecology, the history and the archaeology of Breifne as well as providing extensive reference + to special interests and activities in the region such as fishing, lake and river cruising, walking and cycling, water sports, railways, traditional music, crafts, as well as accommodation and dining.

- $\quad$ DVD and video - 13,000 copies of a 24-minute broadcast quality video were produced which feature a specially-commissioned musical score and interactive DVD database. Copies of the DVD-video were included in each Breifne guidebook (fig. 5).

- Breifne Website - a dedicated best-in-class website with web-mapping capabilities was launched in 2006 and has attracted a lot of attention [5].

- Signage - a suite of attractive pictorial road signs was erected on all major routes into the Breifne region by the local authorities and visitor information panels were erected at key sites.

- Breifne Attractions Guide - a synoptic 41-page visitor attractions guide was launched in spring 2008 to support the marketing drive.
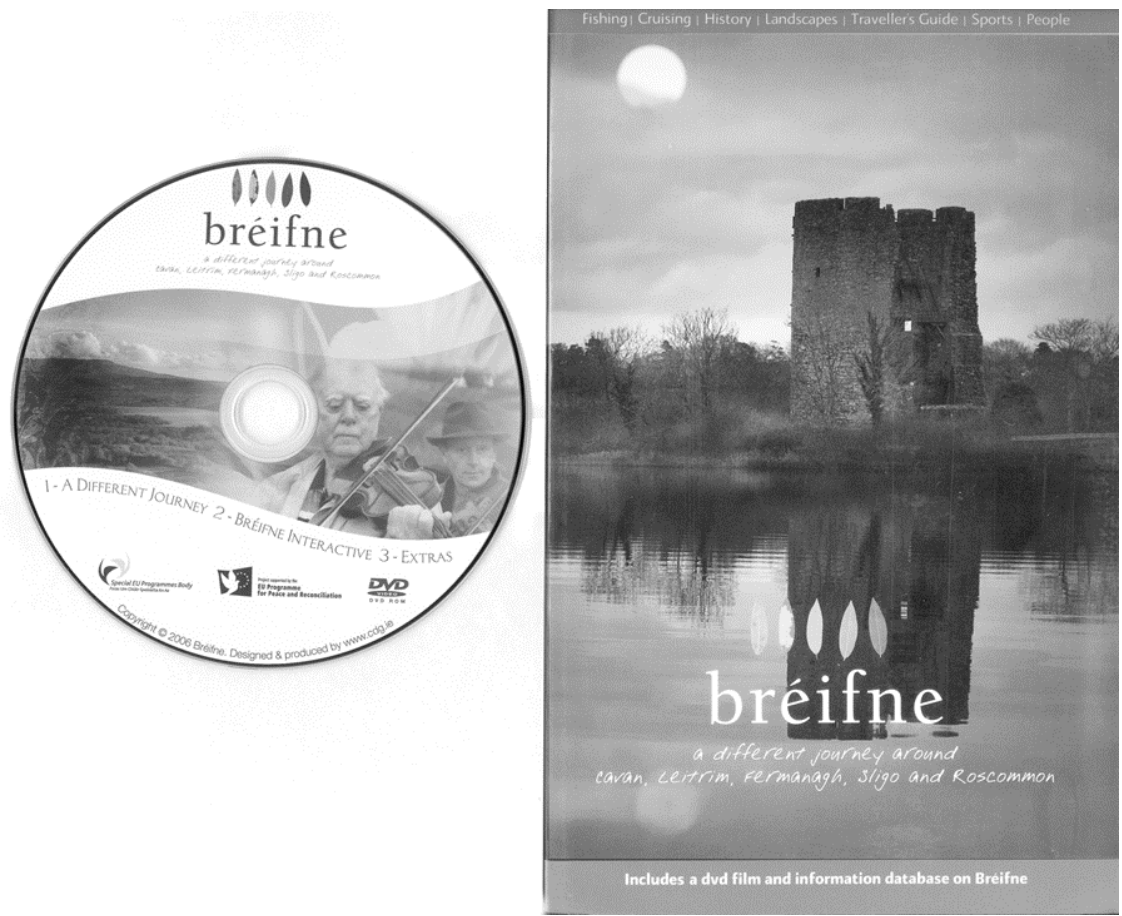

Figure 5: $\quad$ DVD and Breifne guidebook. 


\subsection{Marketing}

The current phase of the Breifne project is aimed at a marketing drive to attract visitors to the region. To this end, practically all copies of the guidebook and DVD-video have been distributed and are being reprinted. Hotels and guesthouses throughout the region have copies for visitor's use. These products, together with the Attractions Guide, have been distributed at Holiday Shows in Dublin and Belfast in 2007 and 2008. Translation of the website pages into German, French and Spanish is currently underway.

\section{The future}

During 2008 it is intended to extend the footprint of the UNESCO-designated Marble Arch European Geopark [6]. Already an extension within Co. Fermanagh itself has been approved by the European Geoparks Network (EGN) on behalf of UNESCO and an application to extend the Geopark across the border into Co. Cavan is currently being considered by the EGN. When approved, hopefully in 2008, Ireland will have the first transnational Geopark in the world. Further extension into other contiguous parts of the Breifne region is also under consideration.

Our experience in Ireland has shown that landscape tourism or geotourism has the capacity to assist in the regeneration of economically-deprived rural areas provided those areas possess significant geological heritage assets to begin with. While external funding can provide critical assistance during the start-up phase, the ongoing involvement and commitment of local authorities and local communities are essential if these initiatives are to be sustainable in the longer term. Landscape tourism initiatives might also assist other areas in the aftermath of ethnic conflict.

\section{Acknowledgements}

The author wishes to acknowledge the work and assistance of the many colleagues he has been engaged with since 1994 on cross-border geotourism initiatives in Ireland. The funding support of the International Fund for Ireland, the European Commission and most of the local authorities across the region is also gratefully acknowledged. The paper is published with the permission of the Director, Geological Survey of Ireland.

\section{References}

[1] O'Connor, P.J. \& Mitchell, I., Cross-border co-operation in geosciences. The Irish Scientist Yearbook, 5, pp. 126, 1997.

[2] McKeever, P.J., Kearns-Mills, N. \& Gallagher, E., Landscapes from Stone: a guide to the scenic landscapes and rocks of Ireland (north). Geological Survey of Ireland - Geological Survey of Northern Ireland, 1998. 
[3] McKeever, P.J. \& Smyth, J., A Story Through Time, Geological Survey of Northern Ireland - Geological Survey of Ireland, 1999.

[4] Geological Survey of Ireland, www.gsi.ie

[5] Breifne, www.breifne.ie

[6] Marble Arch Caves European Geopark, www.marblearchcaves.net 